\title{
Hubungan Pengetahuan Ibu Tentang Gizi Dengan Status Gizi Balita Usia 1-5 Tahun Di Desa Kedawung Wilayah Kerja Puskesmas Ngadi
}

\author{
(The Correlation between Knowledge of Mothers about Nutrition with Nutritional Status of \\ Children Aged 1-5 years in Kedawung Village Ngadi health center working area) \\ Ira Titisari, Finta Isti Kundarti, Mira Susanti \\ Prodi Kebidanan Kediri Jl.KH.Wakhid Hasyim 64 B Kediri \\ Email: iratitisari@ymail.com
}

\begin{abstract}
One of the factors that affect the nutritional status of children is the mother's knowledge. Knowledge is a determinant of attitudes and behavior of the mother. Knowledge required for the application of the provision of food for the nutritional needs so that the nutritional status of children is known. The purpose of this study was analyze the correlation between nutrition knowledge of mothers about nutrition with nutritional status of children aged 1-5 years in Kedawung Village Ngadi health center. The research used cross-sectional method. Total population is 369 children, with proportional sampling techniques and random sampling found 74 respondens and their children as the sample. Data collected by questionnaire and analyzed using the Spearman rank correlation test. The results show respondents have sufficient knowledge about children nutrition is equal to 44.59\%. While most respondents children have good nutrition $(81.08 \%)$. With the Spearman Rank test results obtained $\rho=0,5$ with $t$ formula is $t$ value $(4,9)>t$ table (1.993), then Ho is rejected it means there is a correlation between nutrition knowledge of mothers about nutrition with nutritional status of children aged 1-5 years in Kedawung village Ngadi health center. The conclusion is obtained that the better knowledge of the mother's so nutritional status of children will be close to normal. It is therefore suggested to provide information about nutrition.
\end{abstract}

Keywords : Children, Knowledge, Nutritional Status

\section{Latar Belakang}

Pengetahuan merupakan hasil dari tahu, dan ini terjadi setelah orang melakukan penginderaan terhadap suatu objek tertentu. Penginderaan terjadi melalui pancaindra manusia, yakni indra penglihatan, pendengaran, penciuman, rasa dan raba. Sebagian besar pengetahuan manusia diperoleh melalui mata dan telinga (Notoatmojo, 2003; 121). Pengetahuan adalah sesuatu yang diketahui berkaitan dengan proses pembelajaran (Budiman, 2013; 3).

Gizi adalah suatu proses organisme menggunakan makanan yang dikonsumsi secara normal melalui proses digesti, absorpsi, transportasi, penyimpanan, metabolisme dan pengeluaran zat-zat yang tidak digunakan untuk mempertahankan kehidupan (Sibagariang, 2010; 1). Status Gizi adalah ekspresi dan keadaan keseimbangan dalam bentuk variabel tertentu atau perwujudan dari nutriture dalam bentuk variabel tertentu (Sibagariang, 2010; 1).

Usia 1-5 tahun adalah periode penting dalam tumbuh kembang anak. Masa ini merupakan pertumbuhan dari anak. Apabila asupan makanan balita tidak cukup mengandung zat-zat gizi yang dibutuhkan dan keadaan ini berlangsung lama, akan mengakibatkan perubahan metabolisme dalam otak sehingga otak tidak mampu berfungsi secara normal. Apabila kekurangan gizi ini tetap berlanjut dan semakin berat, maka akan 
menyebabkan pertumbuhan badan balita terhambat, badan lebih kecil. Selain itu kekurangan gizi pada balita dapat mengakibatkan keterlambatan perkembangan motorik yang meliputi perkembangan emosi, tingkah laku (Dewi, 2013; 47). Gangguan emosi mengganggu tingkah laku anak wujud tingkah laku anak seperti merusak barang, menggangu adik, berguling-guling, gagap dan ngompol.

Selama tahun 2012 Dinas Kesehatan Kabupaten Kediri telah melakukan upaya memperbaiki tingkat pertumbuhan/ gizi balita. Berdasarkan distribusi kasus gizi buruk dan gizi kurang pada balita penyebab terbanyak dari kasus adalah karena pola asuh yang kurang baik sebanyak $72,5 \%$. Diantaranya disebabkan karena balita tidak diasuh langsung oleh ibu/ dititipkan, hygiene sanitasi lingkungan yang kurang, pemberian MPASI dini, balita dibawah 2 tahun tidak diberikan ASI dan pemberian asupan makan balita tidak tepat. Penyebab kedua adalah BBLR 15,4\%, ketiga karena penyakit infeksi berulang $4,4 \%$ dan ke empat gemeli dengan prosentase $2,2 \%$.

Berdasarkan data laporan bulanan gizi balita di Wilayah Kabupaten Kediri, dijelaskan bahwa keadaan gizi balita disetiap wilayah berbeda-beda. Wilayah yang memiliki persentase status gizi balita dengan BB normal tertinggi yaitu di Puskesmas Pagu 99,30\% balita dengan BB normal, Puskesmas Purwoasri 97,53\% balita dengan BB normal dan Puskesmas Puncu 97,12\% balita dengan BB normal.

Selain itu masih terdapat balita dengan BB kurang dengan persentase lebih tinggi dari wilayah lainnya. Tercatat lima wilayah yang masih tinggi balita dengan BB kurang. Sejumlah 8,83\% (263 balita) di Puskesmas Ngadi mengalami BB kurang, 2,28\% (68 balita) mengalami BB sangat kurang. Sejumlah 12\% (169 balita) di Puskesmas Ngadi mengalami BB kurang, 2,83\% (40 balita) mengalami BB sangat kurang. Sejumlah 12,5\% (309 balita) di Puskesmas Kepung mengalami BB kurang, 1,01\% (25 balita) mengalami BB sangat kurang. Sejumlah 7,06\% (100 balita) di Puskesmas Plosoklaten mengalami BB kurang, 2,30\% (32 balita) mengalami BB sangat kurang. Sejumlah 9.09\% (96 balita) di Puskesmas Pelas mengalami BB kurang, 1,13\% (11 balita) mengalami BB sangat kurang.

Data dari dinas kesehatan kabupaten kediri tahun 2013 berdasarkan laporan bulanan gizi $(\mathrm{BB} / \mathrm{U})$ balita laki-laki dan perempuan di dapatkan bahwa di wilayah kerja puskesmas Ngadi jumlah balita sebanyak 1413 balita. Balita yang mengalami BB normal adalah 77,26\% (1091 balita), BB lebih mencapai 7,91\% (111 balita), BB kurang mencapai 12\% (169 balita), dan BB sangat kurang mencapai 2,83\% (40 balita). Sedangkan di puskesmas Sambi dengan jumlah balita 2983 balita. Balita yang mengalami BB normal adalah $87,42 \%$ (2607 balita), BB lebih mencapai $1,47 \%$ (43 balita), sejumlah $8,83 \%$ (263 balita) mengalami BB kurang, 2,28\% (68 balita) mengalami BB sangat kurang.

Hasil penelitian yang dilakukan Munthofiah dalam tesisnya, menunjukkan terdapat hubungan yang bermakna antara pertumbuhan dan status gizi anak balita dengan pengetahuan, sikap, maupun perilaku ibu. Di samping itu umur berhubungan dengan status gizi anak balita. Variabel-variabel lainnya seperti pendidikan dan pekerjaan ibu tidak menunjukkan hubungan dengan status gizi anak balita (Munthofiah, 2008).

Hasil studi pendahuluan yang dilakukan di puskesmas Ngadi tercatat bahwa desa Kedawung memiliki jumlah balita dengan gizi kurang tertinggi dari desa lainnya. Sebanyak 27 balita dengan gizi kurang.

Berdasarkan fenomena di atas bahwa perlu adanya peninjauan ulang berkenaan dengan status gizi balita. Dengan demikan peneliti akan melakukan penelitian mengenai adanya "Hubungan Pengetahuan Ibu Tentang Gizi dengan 
Status Gizi Balita Usia 1-5 Tahun Di Desa Kedawung Wilayah Kerja Puskesmas Ngadi."

\section{Metode Penelitian}

Populasi dalam penelitian ini adalah semua ibu yang memiliki balita usia 1-5 tahun beserta balitanya di desa Kedawung wilayah kerja Puskesmas Ngadi Kabupaten Kediri tahun 2014 sejumlah 369 balita. Besarnya sampel ditentukan dengan, jika besar populasi $\leq 1000$, maka sampel bisa diambil 20\% - 30\% (Nursalam, 2008; 91).Maka: 369 x 20\% = $73,8=74$. Teknik sampling yang digunakan adalah proportional sampling yaitu untuk memperoleh sampel yang representatif, pengambilan subjek dari setiap wilayah ditentukan seimbang sebanding dengan banyaknya subjek dalam masing-masing wilayah (Arikunto, 2006; 139). Variabel independent penelitian adalah pengetahuan ibu tentang gizi balita. variabel dependentnya adalah status gizi balita usia 1-5 tahun. Analisis uji statistik yang digunakan, yaitu uji Korelasi Spearman Rank (Rank Correlation Test).

\section{Hasil Penelitian}

1. Pengetahuan Ibu tentang Gizi

\begin{tabular}{cccc}
\hline No & Kategori & Frekuensi & Persentase \\
\hline 1 & Baik & 24 & $32,43 \%$ \\
2 & Cukup & 33 & $44,59 \%$ \\
3 & Kurang & 17 & $22,98 \%$ \\
\hline & Total & 74 & $100 \%$ \\
\hline
\end{tabular}

Berdasarkan tabel 1 dapat dijelaskan bahwa hampir setengah dari responden memiliki cukup pengetahuan tentang gizi balita yaitu sebesar $44,59 \%$.

\section{Status gizi balita}

Berikut ini keadaan status gizi balita dari hasil penimbangan berat badan balita dengan nilai di tabel $\mathrm{BB} / \mathrm{U}$ (WHO).
Tabel 2 Distribusi Status Gizi Balita

\begin{tabular}{cccc}
\hline No & Kategori & Frekuensi & Persentase \\
\hline 1 & Gizi Lebih & 1 & $1,35 \%$ \\
2 & Gizi Baik & 60 & $81,08 \%$ \\
3 & Gizi Kurang & 13 & $17,57 \%$ \\
4 & Gizi Buruk & 0 & 0 \\
\hline & Total & 74 & $100 \%$ \\
\hline
\end{tabular}

Berdasarkan tabel 2 tersebut dapat dijelaskan bahwa sebagian besar responden memiliki status gizi yang baik $(81,08 \%)$.

3.Hubungan Pengetahuan Ibu Tentang Gizi dengan Status Gizi Balita

Berdasarkan hasil penelitian didapatkan hasil pengetahuan ibu tentang gizi dan status gizi balita 1-5 tahun di desa Kedawung wilayah kerja Puskesmas Ngadi sebagai berikut:

Tabel 3 Tabel Silang Pengetahuan Ibu tentang Gizi dengan Status Gizi Balita usia 1-5 tahun

\begin{tabular}{cccccc}
\hline \multicolumn{5}{c}{ Status Gizi } \\
$\begin{array}{c}\text { Pengeta } \\
\text { huan }\end{array}$ & $\begin{array}{c}\text { Gizi } \\
\text { Lebih }\end{array}$ & $\begin{array}{c}\text { Gizi } \\
\text { Baik }\end{array}$ & $\begin{array}{c}\text { Gizi } \\
\text { Kurang }\end{array}$ & $\begin{array}{c}\text { Gizi } \\
\text { Bur } \\
\text { uk }\end{array}$ & Jumlah \\
\hline Baik & 0 & 23 & 1 & 0 & 24 \\
& & $(31,08 \%)$ & $(1,35 \%)$ & & 32,43 \\
& & & & & $\%$ \\
Cukup & 1 & 27 & 5 & 0 & 33 \\
& $(1,35 \%)$ & $(36,49 \%)$ & $(6,76 \%)$ & & 44,60 \\
& & & & & $\%$ \\
Kurang & 0 & 10 & 7 & 0 & 17 \\
& & $(13,51 \%)$ & $(9,46 \%)$ & & 22,97 \\
& & & & & 0 \\
\hline Jumlah & 1 & 60 & 13 & 74 \\
& $1,35 \%$ & $81,08 \%$ & $17,57 \%$ & & $100 \%$ \\
\hline
\end{tabular}

Berdasarkan tabel 3 tabel silang antara pengetahuan ibu tentang gizi dengan status gizi balita hampir setengah dari responden mempunyai pengetahuan yang cukup dan memiliki balita dengan status gizi baik $(36,49 \%)$. Kemudian untuk mengetahui hubungan antara pengetahuan ibu tentang gizi dengan status gizi balita digunakan rumus $\rho=1-\frac{6 \sum \mathrm{bi}^{2}}{n\left(n^{2}-1\right)}$

Berdasarkan perhitungan tersebut didapatkan hasil, $\rho=0,5$. Karena jumlah sampel lebih dari 30, dimana tidak ada 
dalam tabel rho, maka pengujian signifikansinya menggunakan rumus:

$$
\mathrm{t}=r \sqrt{\frac{n-2}{1-r^{2}}}
$$

Berdasarkan hasil perhitungan menggunakan uji korelasi spearman dengan taraf kesalahan sebesar 5\% $(0,05)$ maka diperoleh hasil perhitungan $t=(4,9)$. Kemudian t hitung tersebut dibandingkan dengan $\mathrm{t}$ tabel dengan $\mathrm{dk}=\mathrm{n}-2$ didapatkan $\mathrm{t}$ hitung $(4,9)>\mathrm{t}$ tabel $(1,993)$, maka Ho ditolak, artinya ada hubungan antara pengetahuan ibu tentang gizi dengan status gizi balita usia 1-5 tahun di desa Kedawung wilayah kerja Puskesmas Ngadi.

\section{Pembahasan}

1. Pengetahuan Ibu Tentang Gizi di Desa Kedawung Wilayah Kerja Puskesmas Ngadi

Mengetahui apakah zat gizi tentunya menjadi dasar ibu untuk memiliki tingkat pengetahuan yang lebih tinggi guna memenuhi gizi untuk balitanya. Tentunya sangat berpengaruh sekali mengetahui apa pengertian dari gizi balita tersebut. Sebagian besar ibu belum mengetahuai apa pengertian dari zat gizi tersebut. Hal itu bisa saja dipengaruhi karena masih ada sebagian ibu yang belum memperoleh informasi tentang gizi balita. Kurangnya informasi dapat berpengaruh terhadap pengetahuan ibu. Informasi gizi diperlukan guna menambah pengetahuan ibu akan zat gizi.

Pengetahuan ibu tentang gizi masih tergolong cukup, dari data penelitian diketahui bahwa sebagian besar responden masih rendah pengetahuannya tentang gizi seimbang untuk balita.

Gizi seimbang sangat diperlukan untuk balita. Sangat berpengaruh sekali jika ibu tidak memahami mengenai gizi seimbang akan memberikan makanan dengan seadanya saja, tanpa memperhatikan gizi yang terkandung. Memahami mengenai gizi seimbang balita tentunya dapat membantu ibu untuk menjelaskan bagaimanakah seharusnya memilih makanan untuk balita. Hal tersebut dapat dipengaruhi karena ibu belum mengetahuai apa itu gizi. Oleh karena itu ibu belum memahami apakah gizi seimbang tersebut.

Berdasarkan penjelasan diatas, diketahui bahwa Ibu belum bisa memahami apakah gizi seimbang, dikarenakan tahapan pengetahuan yang paling utama adalah know/ tahu, dengan tidak tahunya mengenai pengertian gizi tersebut, tentunya akan mengurangi pemahaman mengenai gizi lebih dalam lagi.

Penjelasan diatas sejalan dengan pemikiran Budiman (2013) bahwasannya tahapan paling utama dari pengetahuan adalah tingkat know/ tahu. Dimana know/ tahu itu sendiri artinya mengenai kemampuan untuk mengenali dan mengingat peristilahan, definisi, faktafakta, gagasan, pola, urutan, metodologi, prinsip dasar, dan sebagainya. Selanjutnya tingkatan pengetahuan meliputi tahap memahami. Memahami diartikan sebagai suatu kemampuan untuk menjelaskan secara benar tentang objek yang diketahui dan dapat menginterpretasikan materi tersebut secara benar.

Balita sangat mudah sekali menyenangi makanan yang menarik. Seharusnya, hal tersebut dapat digunakan sebagai upaya menarik perhatian balita untuk menambah nafsu makan. Akan tetapi, kebanyakan ibu belum memiliki pengetahuan yang baik mengenai penyusunan menu tersebut. Terutama dalam penyajian dan penggantian menu makanan untuk balita setiap harinya. Kebanyakan responden mengganti menu makanan setelah tiga sampai empat kali penyajian. Sehingga makanan yang disajikan kurang bervariasi. Rendahnya pengetahuan tentang gizi seimbang dapat berakibat dalam pemberian makanan untuk balita. Sehingga ibu sulit mengaplikasikan untuk penyajian makanan untuk balita.

Kurangnya pengetahuan ibu mengenai penyusunan menu dapat 
dipengaruhi karena kurangnya pengalaman ibu dalam pengaplikasian menu tersebut. Hal tersebut dapat dikaitkan dengan jumlah anak yang mereka miliki mayoritas masih memiliki satu balita saja. Pengalaman biasanya diperoleh dengan mengulang kembali pengetahuan yang telah didapat. Memiliki pengalaman yang sedikit tentu sangat berpengaruh dengan pengetahuan yang dimiliki.

Menurut Budiman

Pengalaman sebagai sumber pengetahuan adalah suatu cara untuk memperoleh kebenaran pengetahuan dengan cara mengulang kembali pengetahuan yang diperoleh dalam memecahkan masalah yang dihadapi masa lalu. Selain itu aplikasi pada tahapan pengetahuan diartikan sebagai kemampuan untuk menggunakan materi tersebut secara benar. Dewi (2013) berpendapat pula bahwasanya dalam penyusunan menu balita selain memperhatikan komposisi zat gizi, juga harus memperhatikan variasi menu makanan agar anak tidak bosan.

Tingkat pengetahuan seseorang berbeda-beda, banyak faktor yang mempengaruhinya. Sebagaimana dari hasil penelitian yang telah dilakukan, didapatkan hampir setengah dari responden memiliki pendidikan yang cukup. Berdasarkan karakteristik yang telah didapatkan dari masing-masing responden, banyak faktor yang mempengaruhi perbedaan tingkat pengetahuan yang dimiliki responden. Misalnya saja faktor usia ibu, pendidikan, pekerjaan serta sumber informasi yang telah diperoleh.

Berdasarkan data penelitian didapatkan tingkat pengetahuan ibu tergolong cukup bisa saja dikarenakan salah satu faktor yaitu dari tingkat pendidikan ibu. Walaupun diketahui lebih dari $50 \%$ responden telah berpendidikan SMP, namun dari 33 responden yang memiliki pendidikan cukup tersebut sebagian besar responden adalah dari golongan lulusan SD. Hal ini bisa saja sebagai faktor pendukungnya, dikarenakan pendidikan merupakan salah satu penunjang tingginya pengetahuan. Selain itu faktor lain yang mempengaruhi yaitu kurangnya pengalaman mengenai pemenuhan makanan ditandai dengan hampir $50 \%$ responden yang berpengetahuan cukup memiliki satu balita.

Hal ini sejalan dengan yang dipaparkan Budiman (2013) bahwa pendidikan merupakan sebuah proses pengubahan sikap dan tata laku seseorang atau kelompok dan juga usaha mendewasakan manusia melalui upaya pengajaran dan pelatihan. Penelitian yang dilakukan oleh Fisher (2010) juga menyatakan bahwa berdasarkan data yang didapat saat penelitiannya, rendahnya pengetahuan yang dimiliki responden penelitiannya mungkin disebabkan karena tingkat pendidikan ibu lebih dari separuh adalah tamatan SD, dan bahkan ada yang tidak tamat SD.

Berdasarkan informasi gizi yang didapat dijelaskan bahwa sebagian besar responden sudah memperoleh informasi tentang gizi balita $(79,73 \%)$. Informasi gizi didapatkan dari televisi dan bertanya kepada bidan desa. Banyaknya informasi yang diperoleh akan menambah pengetahuan mengenai gizi balita.

Seperti penjelasan Budiman (2013) menyatakan bahwa lingkungan berpengaruh terhadap proses masuknya pengetahuan ke dalam individu yang berada dalam lingkungan tersebut. Selain itu informasi sebagai transfer pengetahuan guna menyebarkan informasi dengan tujuan tertentu.

Berdasarkan penjelasan diatas, bervariasinya tingkat pengetahuan ibu tentang gizi balita memang sangat dipengaruhi oleh faktor-faktor lain yang sangat erat hubungannya. Selain itu, kebanyakan responden belum mengerti tentang gizi seibang dan pengaplikasiannya dalam kesehariannya. Oleh karena itu pengetahuan ibu di desa Kedawung wilayah kerja Puskesmas 
Ngadi bermacam macam dikarenakan dari karakteristik yang berbeda-beda pula.

2.Status Gizi Balita Usia 1-5 Tahun di Desa Kedawung Wilayah Kerja Puskesmas Ngadi

Banyak faktor yang mempengaruhi pertumbuhan balita misalnya jumlah dan mutu makanan, kesehatan balita, tingkat ekonomi, pendidikan, perilaku, (orang tua/ pengasuh), sosial budaya atau kebiasaan dan ketersediaan bahan makanan. (Depkes RI; 2000). Status Gizi menurut Sibagariang (2010) merupakan ekspresi dan keadaan keseimbangan dalam bentuk variabel tertentu atau perwujudan dari nutriture dalam bentuk variabel tertentu. Jumlah keluarga juga mempengaruhi pemenuhan gizi. Memiliki satu balita maka ibu akan fokus untuk mengurusi dan mengasuhnya, dibandingkan mengasuh dua balita. Seluruh perhatian sepenuhnya akan terletak pada satu balita saja. Sehingga, kebutuhan nutrisi balitanya akan lebih diperhatikan.

Menurut Adriani (2012) besar anggota keluarga merupakan salah satu timbulnya masalah gizi. Jumlah anak yang banyak pada keluarga akan mengakibatkan berkurangnya perhatian dan kasih sayang yang diterima anak juga dapat mengakibatkan berkurangnya kebutuhan primer seperti pemberian makanan.

Pengasuhan sendiri oleh orang tua memungkinkan balita lebih diperhatikan dan mendapat perlakuan khusus serta memberikan yang terbaik untuk balitanya. Secara otomatis fasilitas untuk anak sebagai tujuan utama pengasuhan orang tua akan terpenuhi. Misalnya saja dalam pemenuhan makan, tentunya ibu akan memberikan makanan yang bergizi untuk anaknya.

Faktor lain yaitu mayoritas balita mendapatkan pengasuhan dari kedua orang tuanya. Sangat memungkinkan perhatian serta interaksi yang dekat antara anak dan orang tua dapat menjadi faktor baiknya pertumbuhan balita.
Hal tersebut juga dijelaskan berdasarkan pendapat Supartini (2012) salah satu tujuan utama pengasuhan orang tua adalah memfasilitasi anak untuk mengembangkan kemampuan sejalan dengan tahapan perkembangannya.

Menurut Adriani (2012) pola asuh pada anak merupakan salah satu kebutuhan dasar anak untuk tumbuh kembang, interaksi ibu dan anak terihat erat sebagai indikator kualitas dan kuantitas peranan ibu dalam mengasuh anak.

3. Hubungan Pengetahuan Ibu Tentang Gizi dengan Status Gizi Balita Usia 15 tahun di Desa Kedawung wilayah kerja Puskesmas Ngadi

Pengetahuan tentang gizi yang baik tentunya akan membuat status gizi balita baik pula. Memiliki pengetahuan tentang gizi seimbang yang baik, akan memunculkan sikap untuk menyusun menu makanan balita dengan tepat dan bervariasi. Pada dasarnya pengetahuan akan memunculkan sikap dan membentuk perilaku untuk bertindak dalam pemenuhan gizi balitanya. Selain itu dengan pengetahuan baik akan memperbaik cara ibu dalam pemenuhan gizi balitanya, dengan demikian pertumbuhan dan perkembangan balita dapat terpenuhi. Sehingga pengetahuan yang baik memungkinkan memiliki status gizi yang baik pula.

Kurangnya pengetahuan ibu tentang gizi dapat membuat perilaku ibu dalam memperhatikan gizi balitanya menjadi kurang maksimal. Tentunya akan berbeda dengan yang telah memiliki pengetahuan yang baik. Mayoritas dari responden yang berpengetahuan kurang dan memiliki balita dengan status gizi kurang, mereka kurang baik dalam menyusun menu untuk balitanya. Kebanyakan memberikan menu makanan yang sama untuk balitanya. Selain itu responden belum mengetahui prinsip gizi seimbang balita yang menjadi dasar pemenuhan gizi balita. 
Terjadinya gizi kurang pada balita tersebut bukan berarti ibu tidak memberikan banyak makanan untuk balitanya. Namun dengan kurangnya pengetahuan sikap ibu dalam memilih, mengolah dan menghidangkan makanan untuk balita menjadi kurang benar sehingga zat gizi yang terkandung dalam makanan menjadi berkurang.

Hal ini sejalan dengan pendapat Sibagariang (2010) bahwa salah satu penyebab timbulnya masalah gizi adalah dari faktor pengetahuan. Sama halnya dengan hasil penelitian yang dilakukan oleh Zuraida (2012) berdasarkan analisis regresi logistik berganda diperoleh hasil bahwa pengetahuan gizi ibu dan sikap gizi ibu mempengaruhi status gizi balita, variabel pengetahuan gizi ibu merupakan faktor yang paling kuat hubungannya dengan status gizi balita, hal ini ditunjukkan dengan nilai koefisien regresi yang lebih besar dibandingkan dengan koefisien variabel sikap gizi.

Berdasarkan data yang diperoleh dari penelitian, terdapatnya responden dengan pengetahuan yang baik namun memiliki status gizi kurang dikarenakan karena faktor yang lain yang menyebabkan kondisi berbeda dari yang diharapkan. Kondisi ini dikarenakan balita sebelumnya sakit. Akan tetapi pada saat penimbangan sudah sehat kembali. Hal ini yang menyebabkan terjadinya penurunan berat badan balita sehingga status gizinya menjadi kurang. Selain itu pertambahan berat badan yang relatif sedikit tiap bulannya dapat juga menjadikan pertimbangan mengapa hal tersebut dapat terjadi.

Hal lainnya, terdapatnya responden dengan pengetahuan cukup namun memiliki status gizi lebih dikarenakan karena memang balita tersebut telah memiliki berat badan yang relatif gemuk dari memasuki usia balita. Tercatat pada bulan timbang tahun 2014 ini, bahwa pada responden tersebut juga memiliki status gizi lebih. Hal tersebut dapat pula dipengaruhi dari faktor genetik, bisa dikarenakan ibu dari balita tersebut juga selalu memiliki berat badan yang relatif lebih.

Keadaan lain, terdapat responden yang memiliki pengetahuan kurang namun dapat memiliki balita dengan status gizi yang baik. Adanya hal tersebut dikarenakan, dari responden tersebut ada yang diasuh oleh pengasuh anak, bisa saja pengasuh anak tersebut memiliki pengetahuan yang baik sehingga pelayanan dalam memenuhi gizi balita tersebut menjadi maksimal. Selain itu, dengan rutinnya untuk datang timbang ke posyandu memungkikan perhatian bidan terhadap balita tersebut menjadi terpantau status gizinya.

Hasil penelitian menunjukkan adanya hubungan pengetahuan ibu tentang gizi dengan status gizi balita. Semakin baik pengetahuan ibu tentang gizi maka status gizi balita akan semakin mendekati normal. Pengetahuan tentang gizi berperan penting dalam pembentukan sikap ibu, yang nantinya akan memunculkan perilaku untuk memberikan asupan nutrisi yang baik untuk balitanya. Pengetahuan ibu tentang gizi akan menjadikan ibu lebih paham mengenai zat-zat gizi yang dibutuhkan balitanya. Baiknya pengetahuan ibu akan menumbuhkan perilaku yang baik untuk pengolahan bahan pangan, menyajikan dan menyimpan makanan agar zat-zat gizi yang terkandung tidak hilang.

Pengetahuan ibu tentang gizi penting untuk pertumbuhan balita, jika ibu tahu dan memperhatikan gizi balitanya tersebut, ibu akan menambah informasi dan berusaha memberi yang terbaik untuk balitanya. Pengetahuan ibu berpengaruh pada perilaku ibu dalam memenuhi gizi balitanya. Walaupun banyak faktor lain yang mempengaruhi pertumbuhan balita. Secara tidak langsung, pengetahuan ibu berperan penting dalam peningkatan berat badan balita dan menentukan status gizi balita. Semakin baik pengetahuan ibu tentang gizi maka status gizi balitanya juga akan baik. 


\section{Kesimpulan}

1. Pengetahuan ibu tentang gizi balita usia 1-5 tahun di desa Kedawung wilayah kerja Puskesmas Ngadi hampir setengah dari responden adalah cukup.

2. Status gizi sebagian besar balita usia 1-5 tahun di desa Kedawung wilayah kerja Puskesmas Ngadi adalah baik.

3. Ada hubungan pengetahuan ibu tentang gizi dengan status gizi balita usia 1-5 tahun di desa Kedawung wilayah kerja Puskesmas Ngadi.

\section{Saran}

1. Bagi Peneliti Selanjutnya

Diharapkan lebih mengembangkan penelitian ini lebih dalam dan luas lagi tentang hubungan pengetahuan ibu tentang gizi dengan status gizi balita.

2. Bagi Tempat Penelitian

a. Dengan adanya informasi ini diharapkan bagi ibu yang mempunyai balita dapat meningkatkan lagi pengetauannya tentang gizi balita.

b. Perlu adanya peran aktif tenaga kesehatan setempat untuk melakukan usaha promotif seperti pembuatan banner, leaflet serta penggalakan penyuluhan kesehatan dalam rangka pemberian informasi mengenai gizi balita, sehingga masyarakat bisa mengetahui informasi tersebut.

\section{Daftar Pustaka}

Adriani, M dan Bambang W. 2012. Peranan Gizi Dalam Siklus Kehidupan. Jakarta: Kencana Prenada Media Group 2012. Pengantar Gizi Masyarakat. Jakarta: Kencana Prenada Media Group

Almatsier, S. 2005. Prinsip Dasar Ilmu Gizi. Jakarta: Gramedia Pustaka Utama

Arikunto, S. 2006. Prosedur Penelitian. Jakarta: Rineka Cipta

Budiman \& A. Riyanto. 2013. Kapita Selekta Kuesioner. Jakarta: Salemba Medika
Bungin, B. 2010. Metodologi Penelitian Kuantitatif. Jakarta: Kencana

Dahlan, M.S. 2008. Statistik Untuk kedokteran dan Kesehatan. Jakarta: Salemba Medika

Dewi, A.B.F.K. Nurul P. Ibnu F. 2013. Ilmu Gizi Untuk Praktisi Kesehatan. Yogyakarta: Graha Ilmu

Fisher, E. dkk. 2010. Hubungan Tingkat Pengetahuan Ibu Tentang Gizi Dengan Status Gizi Balita Di Desa Sioban Kabupaten Kepulauan Mentawai. Program Studi pendidikan Biologi STKIP PGRI Sumatera Barat Jurusan Biologi Universitas Negeri Padang. Diakses tanggal 4 Agustus 2014 jam 16.00 WIB

Kabid Kesga \& Gizi. Dinas Kesehatan Kabupaten Kediri. Data Laporan Gizi. 2012

Dinas Kesehatan Kabupaten Kediri. Data Laporan Gizi. 2013

Kurniawati, E. 2010. Hubungan Tingkat Pengetahuan Ibu Tentang Gizi Dengan Status Gizi Balita Di Kelurahan Baledono, Kecamatan Purworejo, Kabupaten Purworejo. Diakses tanggal 4 Agustus 2014 jam 15.00 WIB

Mahfoedz, I. dkk. 2010. Teknik Menyusun KTI-Skripsi-Tesis-Tulisan dalam Jurnal Bidang Kebidanan, Keperawatan dan Kesehatan. Yogyakarta : Fitramaya.

Munthofiah,S. 2008. Hubungan Antara Pengetahuan, Sikap, Dan Perilaku Ibu Dengan Status Gizi Anak Balita. Diakses tanggal 15 Maret 2014 jam 15.15 WIB

Notoatmodjo, S. 2012. Metodologi Penelitian Kesehatan. Jakarta: Rineka Cipta . 2005. Metodologi Penelitian Kesehatan. Jakarta: Rineka Cipta

Nursalam. 2008. Konsep Dan Penerapan Metodologi Penelitian Ilmu Keperawatan. Jakarta: Salemba Medika 
Puskesmas Ngadi. 2013. Data Laporan Gizi Tahun 2013

2014. Data Laporan Bulan Timbang Bulan Februari 2014

Riduwan. 2010. Metode dan Teknik Menyusun Tesis. Bandung: Alfabeta

Santoso, S. dan Anne L. 2009. Kesehatan dan Gizi. Jakarta : Rineka Cipta

Suyanto, S \& U. Salamah. 2009. Riset Kebidanan, Metodologi \& Aplikasi. Yogyakarta: Mitra Cendekia

Septiari, B. 2012. Mencetak Balita Cerdas dan Pola Asuh Orang Tua. Yogyakarta: Nuha Medika

Setiawati, R. dkk. 2012. Hubungan Pengetahuan dan Sikap Ibu Tentang Pemberian Makanan Tambahan Dengan Berat Badan Bayi Usia 612 Bulan Di Posyandu Kesamben Blitar. Diakses tanggal 15 Maret 2014 jam 15.00

Sibagariang, E. 2010. Gizi Dalam Kesehatan Reproduksi. Jakarta: Trans Info Media

Soediaoetomo, A. D. 2010. Ilmu Gizi 1. Jakarta: Dian Rakyat

Sugiyono. 2010. Statistika untuk Penelitian. Bandung: Alfabeta

2011. Metode Penelitian Kuantitatif Kualitatif dan $R \& D$. Bandung: Alfabeta

Supariasa, I.D.N. dkk. 2003. Penilaian Status Gizi. Jakarta: EGC

Wawan, A dan Dewi. (2011). Teori \& Pengukuran Pengetahuan, Sikap dan Perilaku Manusia. Yogjakarta : Nuha Medika.

Wibowo, H.T. 2012. Hubungan Antara Tingkat Pengetahuan Ibu Balita Tentang Gizi Dengan Status Gizi Balita (1-5 Tahun) Di Posyandu Dusun Modopuro Desa Modopuro Kecamatan Mojosari Mojokerto. Diakses tanggal 1 April 2013 jam 14.30 WIB

Zuraida, R dan Julita N. 2010. Hubungan Antara Pengetahuan Dan Sikap Gizi Ibu Dengan Status Gizi Balita Di Wilayah Kerja Puskesmas Rajabasa
Indah Kelurahan Rajabasa Raya Bandar Lampung. Fakultas Kedokteran Universitas Lampung . juli_niezz@yahoo.com. Diakses tanggal 4 Agustus 2014 jam 16.20 WIB 